\title{
STEROIDAL SAPONINS FROM THE SEEDS OF HYOSCYAMUS NIGER L.
}

\author{
Irina Lunga $^{\mathrm{a} *}$, Pavel Kintia ${ }^{\mathrm{a}}$, Stepan Shvets ${ }^{\mathrm{a}}$, Carla Bassarello ${ }^{\mathrm{b}}$, Sonia Piacente ${ }^{\mathrm{b}}$, Cosimo Pizza $^{\mathrm{b}}$ \\ ${ }^{a}$ Institute of Genetics and Physiology of Plants, Academy of Sciences of Moldova,Padurii 20, 2004, Chisinau, Moldova \\ *lunga_irina@yahoo.com, tel. 37322 555259,fax 37322556180 \\ ${ }^{b}$ Department of Pharmaceutical Sciences, University of Salerno, Ponte Don Melillo, 84084, Fisciano, Salerno, Italy
}

\begin{abstract}
Ten steroidal saponins have been isolated form the seeds of Hyoscyamus niger L. for the first time and their structures have been elucidated. Seven saponins belong to spirostane series, two are furostane-type and one is pregnane glycoside. Hyoscyamosides $\mathbf{B}, \mathbf{C}$ and $\mathbf{C}_{2}$ are new steroidal saponins, which have never been reported before in literature. Complete assignments of the ${ }^{1} \mathrm{H}$ and ${ }^{13} \mathrm{C}$ NMR chemical shifts for all these glycosides were achieved by means of one- and two-dimensional NMR techniques, including 1H-1H COSY, HSQC, HMBC and ROESY spectra.
\end{abstract}

Keywords: Hyoscyamus niger L., steroidal saponins.

\section{Introduction}

Steroidal saponins and pregnanes have established themselves as an important class of biologically active compounds. Pharmacological studies in recent years have shown that these compounds possess antitumor [1-3], bone resorbing [4] and antifungal activities [5]. A number of such compounds have been isolated from the plants, especially the Solonaceae family [6].

Hyoscyamus niger L. (Solonaceae) is a plant native to Europe and Asia and its leaves and seeds have been used in traditional medicine for the treatment of nervous and convulsive diseases. Previous works have been focused only to the alkaloid constituents of this plant and it has never been reported about its steroidal saponins. This fact and our interest in secondary metabolites of Solonaceae family prompted us to perform the phytochemical investigation of the seeds of Hyoscyamus niger L. Our investigation yielded three new steroidal saponins for which we propose the names hyoscyamosides $\mathbf{B}$ (1), C (2) and $\mathbf{C}_{2}$ (3) and seven known compounds - hyoscyamosides A (4), $\mathbf{B}_{\mathbf{1}}$ (5), $\mathbf{B}_{2}(\mathbf{6}), \mathbf{B}_{3}$ (7), C1 (8), E (9) and F1 (10).

\section{Results and discussion}

The buthanol extract, containing steroidal saponins was chromatographed on silica gel column and also using prep. HPLC to afford ten compounds, 1-10. Among them, compounds 4-10 were identified as 3-O- $\beta$-D-galactopyranoside-(25 R)-5 $\alpha$-spirostan-3 $\beta$-ol (4) [7], 3-O- $\beta$-D-glucopyranosyl-( $1 \rightarrow 4)-\beta$-D-galactopyranoside-(25 R)-5 $\alpha$-spirostan-3 $\beta$ -

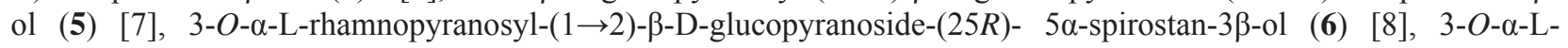

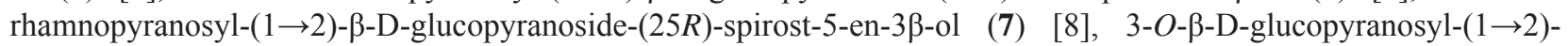
$\beta$-D-glucopyranosyl-( $(1 \rightarrow 4)-O-\beta$-D-galactopyranoside- $(25 R)-5 \alpha$ - spirostan-3 $\beta$-ol (8) [9], 3-O- $\beta$-D-glucopyranosyl$(1 \rightarrow 4)-O-\beta$-D-galactopyranoside-(25R)-26-O- $\beta$-D-glucopyranosyl-5 $\alpha$-furostan-3 $\beta, 22 \alpha, 26$-triol $\quad(9) \quad[10]$, 3-O- $\beta$-Dglucopyranosyl- $(1 \rightarrow 2)$ - $\beta$-D-glucopyranosyl- $(1 \rightarrow 4)-O$ - $\beta$-D-galactopyranoside- $(25 R)-26-O$ - $\beta$-D-glucopyranosyl- $5 \alpha-$ furostan-3 $\beta, 22 \alpha, 26$-triol (10) [10], on the basis of their spectroscopic data by comparison with literature data.

The ${ }^{1} \mathrm{H}$ NMR spectrum of 1 showed signals for four steroidal methyl groups at $\delta 0.82(3 \mathrm{H}, \mathrm{s}, \mathrm{Me}-18), 0.89(3 \mathrm{H}$, s, Me-19), $1.00(3 \mathrm{H}, \mathrm{d}, \mathrm{Me}-21), 1.12(3 \mathrm{H}, \mathrm{d}, \mathrm{Me}-27)$, two methine proton signals at $\delta 3.68(1 \mathrm{H}, \mathrm{m}, \mathrm{H}-3)$ and $4.41(1 \mathrm{H}$, $\mathrm{m}, \mathrm{H}-16)$ indicative of secondary alcoholic functions and two anomeric protons protons at $\delta 4.38(1 \mathrm{H}, \mathrm{d}, J=7.5 \mathrm{~Hz})$, $4.53(1 \mathrm{H}, \mathrm{d}, J=7.5 \mathrm{~Hz})$, giving correlations with carbon signals at $\delta 103.5$ and 105.0, respectively. The chemical shifts of all the individual protons of this sugar unit were ascertained from a combination of 1D-TOCSY and DQFCOSY spectral analysis, and the ${ }^{13} \mathrm{C}$ chemical shifts of their relative carbons could be assigned unambiguously from the HSQC spectrum. These data showed the presence of two sugars - $\beta$-D-galactose and $\beta$-D-glucose. The HMBC spectrum showed key correlation peaks between the proton signal at $\delta 4.38\left(\mathrm{H}-1_{\text {gal }}\right)$ and the carbon resonance at $\delta 78.9(\mathrm{C}-3$ of the aglycon) and at $\delta 4.53\left(\mathrm{H}-1_{\mathrm{glc}}\right)$ and the carbon resonance at $\delta 80.7\left(\mathrm{C}-3_{\mathrm{gal}}\right)$. On the basis of the above results the structure of 1 was determined as 3-O- $\beta$-D-glucopyranosyl- $(1 \rightarrow 3)-\beta$-D- galactopyranoside - (25 R)-5 $\alpha$-spirostan - 3 $\beta$-ol and was named by us hyoscyamoside $\mathbf{B}$.

The ${ }^{1} \mathrm{H}$ NMR spectrum of $\mathbf{2}$ showed identical aglycon moiety of compound 1 -(25R)- $5 \alpha$ spirostan-3 $\beta$-ol. One primary alcoholic function at $\delta 67.7$ (C-26) suggested the occurrence of a glycoside spirostanol skeleton. The ${ }^{1} \mathrm{H}$ NMR spectrum showed signals for three anomeric protons at $\delta 4.39(1 \mathrm{H}, \mathrm{d}, J=7.5 \mathrm{~Hz}), 4.56(1 \mathrm{H}, \mathrm{d}, J=7.5 \mathrm{~Hz})$, and 4.69 $(1 \mathrm{H}, \mathrm{d}, J=7.5 \mathrm{~Hz})$. 1D-TOCSY and DQF-COSY spectral analysis of the sugar moiety revealed the presence of one $\beta$-galactopyranosyl unit $(\delta 4.39)$ and two $\beta$-glucopyranosyl units ( $\delta 4.56$ and 4.69). The HMBC spectrum showed 
key correlation peaks between the proton signal at $\delta 4.39\left(\mathrm{H}-1_{\text {gal }}\right)$ and the carbon resonance at $\delta 79.1(\mathrm{C}-3$ of the aglycon), the proton signal at $\delta 4.56\left(\mathrm{H}-1_{\mathrm{glc}}\right)$ and the carbon resonance at $\delta 78.1\left(\mathrm{C}-2_{\mathrm{gal}}\right)$, the proton signal at $\delta 4.69$ $\left(\mathrm{H}-1_{\mathrm{glc}}\right)$ and the carbon resonance at $\delta 82.5\left(\mathrm{C}-3_{\mathrm{gal}}\right)$. Thus, the structure of compound 2 was deduced as 3-O- $\{[\beta-\mathrm{D}-$ glucopyranosyl- $(1 \rightarrow 2)]-[\beta-D$ - glucopyranosyl- $(1 \rightarrow 3)]-\beta$-D-galactopyranoside $\}-(25-\mathrm{R})-5 \alpha$-spirostan-3 $\beta$-ol, which we named hyoscyamoside $\mathbf{C}$.

${ }^{1} \mathrm{H}$ NMR spectrum of compound 3 displayed signals for three tertiary methyl groups at $\delta 0.90(3 \mathrm{H}, \mathrm{s}, \mathrm{Me}-19)$, $0.91(3 \mathrm{H}, \mathrm{s}, \mathrm{Me}-18)$ and $2.28(3 \mathrm{H}, \mathrm{s}, \mathrm{Me}-21)$, one olefinic proton at $\delta 6.91(1 \mathrm{H}, \mathrm{m}, \mathrm{H}-16)$ together with three anomeric protons $(1 \mathrm{H}, \mathrm{d}, \delta 4.40 ; 1 \mathrm{H}, \mathrm{d}, \delta 4.56 ; 1 \mathrm{H}, \mathrm{d}, \delta 4.69)$. On the other hand, the ${ }^{13} \mathrm{C}-\mathrm{NMR}$ signals due to a total of $21 \mathrm{carbon}$ signals originating from the sapogenol were composed of three methyl groups at $\delta 12.2,15.7$, and 26.8, one oxygenbearing methine carbon at $\delta 79.1$ (C-3), one carbonyl group at $\delta 199.3$ (C-20), two quaternary carbons at $\delta 35.7$ and 47.2, four methine carbons at $\delta 34.7,45.9,56.1$ and 57.3, eight methylene carbons at $\mathrm{d} 21.3,29.5,30.0,32.8,32.9$, 35.0, 35.7 and 37.9, and two olefinic carbons at $\mathrm{d}$ 147.0 and 156.4. The HMBC disclosed the connectivities of the above functional carbons to form a pregnane skeleton. Using 1D-TOCSY, COSY, HSQC and HMBC spectra the sugar chain were characterized as $\beta$-D-galactose, two $\beta$-D-glucose. HMBC spectrum showed key correlation picks between sugars anomeric protons and attached carbons at $\delta 4.40\left(\mathrm{H}-1_{\text {gal }}\right)$ and $79.1(\mathrm{C}-3 \mathrm{agl}), \delta 4.56\left(\mathrm{H}-1_{\mathrm{glc}}\right)$ and $80.2\left(\mathrm{C}-4_{\mathrm{gal}}\right), \delta 4.69\left(\mathrm{H}-1_{\mathrm{glcI}}\right)$ and $84.7\left(\mathrm{C}-2_{\mathrm{glc}}\right)$. Thus, compound 3 was elucidated as 3 -O $\beta$-D-glucopyranosyl $\left.(1 \rightarrow 2)\right]-\beta$-D-glucopyranosyl- $(1 \rightarrow 4)$ $\beta$-D-galactopyranosyl-5 $\alpha$-pregn-16-en-20-one-3 $\beta$-ol, for which we proposed the name hyoscyamoside $\mathbf{C}_{2}$.

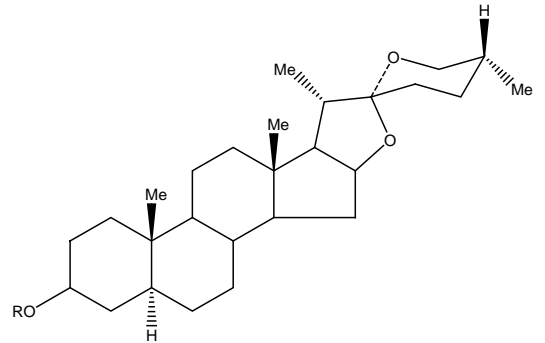

1: $\mathrm{R}=\mathrm{Glc}(1-3) \mathrm{Gal}$

2: $\mathrm{R}=[\mathrm{Glc}(1-3)][\mathrm{Glc}(1-2)] \mathrm{Gal}$

4: $\mathrm{R}=\mathrm{Gal}$

5: $\mathrm{R}=\mathrm{Glc}(1-4) \mathrm{Gal}$

6: $\mathrm{R}=\mathrm{Rha}(1-2) \mathrm{Glc}$

8: $\mathrm{R}=\mathrm{Glc}(1-2) \mathrm{Glc}(1-4) \mathrm{Gal}$

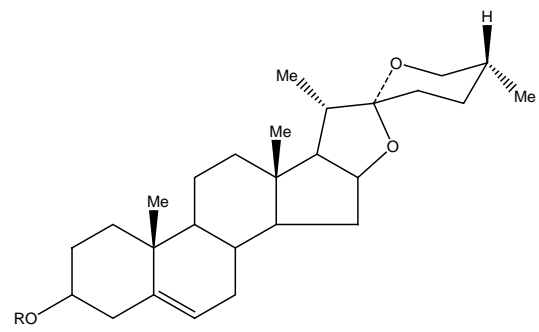

7: R=Rha(1-2)Glc<smiles>CC(=O)C1=CCC2C3CC[C@H]4CC(O)CC[C@]4(C)C3CC[C@]12C</smiles>

3: $\mathrm{R}=\mathrm{Glc}(1-2) \mathrm{Glc}(1-4) \mathrm{Gal}$

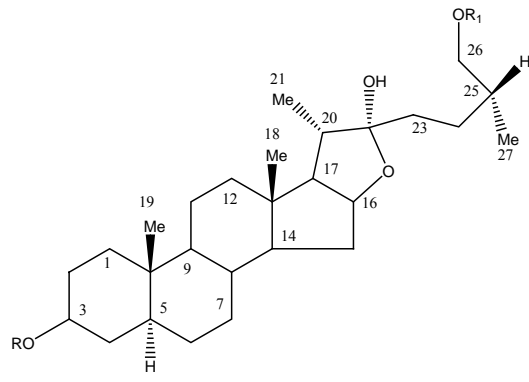

9: $\mathrm{R}=\mathrm{Glc}(1-4) \mathrm{Gal}$ $\mathrm{R}_{1}=\mathrm{Glc}$

10: $\mathrm{R}=\mathrm{Glc}(1-2) \mathrm{Glc}(1-4) \mathrm{Gal}$ $\mathrm{R}_{1}=\mathrm{Glc}$ 
Table 1

${ }^{13} \mathrm{C}$ NMR spectral data (150 MHz, $\left.\mathrm{CD}_{3} \mathrm{OD}\right)$ of saponins (1-3)

\begin{tabular}{|c|c|c|c|}
\hline arbon & 1 & 2 & 3 \\
\hline 1 & 37.9 & 37.9 & 37.9 \\
\hline 2 & 30.4 & 30.2 & 30.0 \\
\hline 3 & 78.9 & 79.1 & 79.1 \\
\hline 4 & 34.9 & 35.1 & 35.0 \\
\hline 5 & 45.8 & 45.8 & 45.9 \\
\hline 6 & 32.9 & 32.9 & 29.5 \\
\hline 7 & 34.6 & 34.6 & 32.9 \\
\hline 8 & 36.0 & 36.0 & 34.7 \\
\hline 9 & 55.2 & 55.2 & 56.1 \\
\hline 10 & 36.5 & 36.4 & 35.7 \\
\hline 11 & 21.5 & 21.5 & 21.3 \\
\hline 12 & 40.5 & 40.5 & 35.7 \\
\hline 13 & 41.8 & 41.8 & 47.2 \\
\hline 14 & 57.5 & 57.5 & 57.3 \\
\hline 15 & 32.3 & 32.3 & 32.9 \\
\hline 16 & 82.1 & 82.2 & 147.0 \\
\hline 17 & 63.7 & 63.7 & 156.4 \\
\hline 18 & 16.7 & 16.7 & 15.7 \\
\hline 19 & 12.5 & 12.6 & 12.2 \\
\hline 20 & 42.6 & 42.6 & 199.3 \\
\hline 21 & 14.2 & 14.2 & 26.8 \\
\hline 22 & 110.5 & 110.5 & \\
\hline 23 & 32.2 & 32.1 & \\
\hline 24 & 29.1 & 29.1 & \\
\hline 25 & 31.2 & 31.2 & \\
\hline 26 & 67.7 & 67.7 & \\
\hline 27 & 16.7 & 16.7 & \\
\hline $1^{\prime}$ & 103,5 & 103,2 & 102.9 \\
\hline $2^{\prime}$ & 72,9 & 78,1 & 72.9 \\
\hline $3^{\prime}$ & 80,7 & 82.5 & 75.3 \\
\hline $4^{\prime}$ & 70,5 & 71,7 & 80.2 \\
\hline 5 & 75,6 & 75,4 & 77.8 \\
\hline $6^{\prime}$ & 60,3 & 60,1 & 60.4 \\
\hline $1 "$ & 105,0 & 104,9 & 104.5 \\
\hline $2 "$ & 75,5 & 75,5 & 84.7 \\
\hline $3 "$ & 78,3 & 78,0 & 77.8 \\
\hline 4" & 71,2 & 71,2 & 71.4 \\
\hline $5 \%$ & 78,9 & 78,9 & 78.6 \\
\hline 6" & 63,1 & 62,9 & 62.5 \\
\hline
\end{tabular}

\section{Experimental}

The seeds of Hyoscyamus niger L. has been collected in the scientific research field of Institute of Scientific Researches and Technological Constructions for Tobacco and Tobacco Products of Moldova in November 2001 year. The voucher specimen has been deposited in Laboratory of selection under direction of Doctor in Biology Kalkei E.D.

Dry powdered seeds $(500 \mathrm{~g})$ were extracted three times in $50^{\circ} \mathrm{C}$ with $\mathrm{n}$-buthanol saturated with water. The received n-butanol-water extract was evaporated and then purified with chloroform. After purification it was crystallised in acetone. The residue was dried in vacuum at $40^{\circ} \mathrm{C}$ and the sum of steroidal saponins has been obtained as yellow powder in $3.7 \%$ yield. $3 \mathrm{~g}$ of extract has been chromatographied on silica gel column $(30-500 \mathrm{~mm}, 60-100 \mu \mathrm{m}$, Merck). The column was eluted with system chloroform-methanol-water $(8: 2: 0 \rightarrow 20: 10: 1)$ and $4 \mathrm{ml}$ fractions were 
collected. Fractions showing identical characteristics [TLC, silica gel, chloroform-methanol (4:1)] were combined. Two subfractions, (A) and (B) were obtained, which were further separated on a $\mathrm{C}_{18}$ column (7,8x300mm, LiChroprep RP18, $25-40 \mu \mathrm{m}$, XTerra Waters) using a $\mathrm{H}_{2} \mathrm{O} / \mathrm{MeOH}(60-80 \% \mathrm{MeOH})$ isocratic. Ten single compounds were isolated.

NMR experiments were performed on a Bruker DRX-600 spectrometer (Bruker BioSpin GmBH, Rheinstetten, Germany) at $300 \mathrm{~K}$ dissolving all the samples in $\mathrm{CD}_{3} \mathrm{OD}$ (Carlo Erba, 99.8\%). The standard pulse sequence and phase cycling were used for DQF-COSY, HSQC and HMBC spectra. The NMR data were processed using UXNMR software.

ESI-MS in the positive ion mode was performed using a Finnigan LCQ Deca ion trap instrument from Thermo Finnigan (San Jose, CA) equipped with Xcalibur software.

HPLC separations were carried out on a Waters 590 system equipped with a Waters R401 refractive index detector, a Waters XTerra Prep $\mathrm{MSC}_{18}$ column (300 x $7.8 \mathrm{~mm}$ i.d.) and a Rheodyne injector.

Column chromatography was performed over Silica gel (0.1-0.06 mm, Merck). TLC was performed on silica gel plates (Merck precoated silica gel $60 \mathrm{~F}_{254}$ ). All solvents for chromatographic separation were of analytical grade from Carlo Erba (Rodano, Italy). HPLC grade water $(18 \mathrm{~m} \Omega$ ) was prepared using a Millipore Milli-Q purification system (Millipore Corp., Bedford, MA).

1. HRMS m/z 741.452[calculated for $\left.\mathrm{C}_{39} \mathrm{H}_{64} \mathrm{O}_{13}(\mathrm{M})^{+}\right] ; 579.3[\mathrm{M}-162]^{+} ;{ }^{1} \mathrm{H}$ NMR (aglycon) $\delta 4.41(1 \mathrm{H}, \mathrm{m}$, H-16), 3.68 (1H, m, H-3), 3.46 (1H, m, H-26a), 3.33 (1H, m, H-26b), 0.88 (3H, s, Me-19), 0.81 (3H, s, Me-18), 0.98 $(3 \mathrm{H}, \mathrm{d}, \mathrm{Me}-21), 1.10$ (3H, d, Me-27). (sugars) $\delta 4.38$ (d, J=7.4 Hz, H-1Gal), 3.51 (dd, J=7.4 and 9.0 Hz, H-2Gal), 3.76 (dd, $J=4.0$ and $9.0 \mathrm{~Hz}, \mathrm{H}-3 \mathrm{Gal}), 3.85$ (dd, $J=2.5$ and $4.0 \mathrm{~Hz}, \mathrm{H}-4 \mathrm{Gal}$ ), 3.58 (ddd, $J=2.5,2.5$ and 4.5 Hz, H-5Gal), 3.63 (dd, $J=4.5$ and $12.0 \mathrm{~Hz}, \mathrm{H}-6 \mathrm{aGal}), 3.90$ (dd, $J=2.5$ and $12.0 \mathrm{~Hz}, \mathrm{H}-6 \mathrm{bGal}$ ), 4.53 (d, J=7.5 Hz, H-1Glc), 3.29 (dd, $J=7.5$ and $9.0 \mathrm{~Hz}, \mathrm{H}-2 \mathrm{Glc}$ ), 3.39 (dd, $J=9.0$ and $9.0 \mathrm{~Hz}, \mathrm{H}-3 \mathrm{Glc}$ ), 3.24 (dd, $J=9.0$ and $9.0 \mathrm{~Hz}, \mathrm{H}-4 \mathrm{Glc}$ ), 3.31 (ddd, $J=2.5,4.5$ and $9.0 \mathrm{~Hz}, \mathrm{H}-5 \mathrm{Glc}$ ), 3.62 (dd, $J=4.5$ and $11.5 \mathrm{~Hz}, \mathrm{H}-6 \mathrm{GGlc}$ ), 3.93 (dd, J=2.5 and $11.5 \mathrm{~Hz}, \mathrm{H}-6 \mathrm{bGlc}$ ). For ${ }^{13} \mathrm{C}$ NMR see Table 1 .

2. HRMS, $\mathrm{m} / \mathrm{z} 903.443$ [calculated for $\left.\mathrm{C}_{45} \mathrm{H}_{74} \mathrm{O}_{18}(\mathrm{M})^{+}\right] ; 741.6[\mathrm{M}-162]^{+} ; 579[\mathrm{M}-2 \times 162]^{+} ;{ }^{1} \mathrm{H}$ NMR (aglycon)

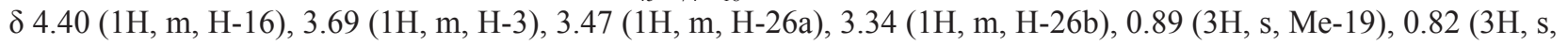
Me-18), 0.99 (3H, d, Me-21), 1.27(3H, d, Me-27). (sugars) 84.39 (d, J=7.4 Hz, H-1Gal), 3.84 (dd, J=7.4 and 9.0 Hz, $\mathrm{H}-2 \mathrm{Gal}$ ), 3.78 (dd, $J=4.0$ and $9.0 \mathrm{~Hz}, \mathrm{H}-3 \mathrm{Gal}$ ), 4.02 (dd, $J=2.5$ and $4.0 \mathrm{~Hz}, \mathrm{H}-4 \mathrm{Gal}$ ), 3.69 (ddd, $J=2.5,2.5 \mathrm{and} 4.5 \mathrm{~Hz}$, H-5Gal), 3.62 (dd, $J=4.5$ and $12.0 \mathrm{~Hz}, \mathrm{H}-6 \mathrm{GGal}), 3.95$ (dd, $J=2.5$ and $12.0 \mathrm{~Hz}, \mathrm{H}-6 \mathrm{bGal}$ ), 4.56 (d, $J=7.5 \mathrm{~Hz}, \mathrm{H}-1 \mathrm{Glc}$ ), 3.30 (dd, $J=7.5$ and $9.0 \mathrm{~Hz}, \mathrm{H}-2 \mathrm{Glc}$ ), 3.60 (dd, $J=9.0$ and $9.0 \mathrm{~Hz}, \mathrm{H}-3 \mathrm{Glc}$ ), 3.35 (dd, $J=9.0$ and 9.0 Hz, H-4Glc), 3.25 (ddd, $J=2.5,4.5$ and $9.0 \mathrm{~Hz}, \mathrm{H}-5 \mathrm{Glc}$ ), 3.60 (dd, $J=4.5$ and $11.5 \mathrm{~Hz}, \mathrm{H}-6 \mathrm{GGlc}$ ), 3.93 (dd, $J=2.5$ and 11.5 Hz, H-6bGlc), 4.69 (d, J=7.5 Hz, H-1GlcI), 3.29 (dd, J=7.5 and 9.0 Hz, H-2GlcI), 3.36 (dd, J=9.0 and 9.0 Hz, H-3GlcI), 3.40 (dd, $J=9.0$ and $9.0 \mathrm{~Hz}, \mathrm{H}-4 \mathrm{GlcI}$ ), 3.42 (ddd, $J=2.5,4.5$ and $9.0 \mathrm{~Hz}, \mathrm{H}-5 \mathrm{GlcI}$ ), 3.69 (dd, $J=4.5$ and $11.5 \mathrm{~Hz}, \mathrm{H}-6 \mathrm{aGlcI}$ ), 3.82 (dd, $J=2.5$ and $11.5 \mathrm{~Hz}, \mathrm{H}-6 \mathrm{bGlcI})$. For ${ }^{13} \mathrm{C}$ NMR see Table 1 .

3. HRMS, $m / z$ [calculated for $\left.\mathrm{C}_{39} \mathrm{H}_{50} \mathrm{O}_{20}(\mathrm{M})^{+}\right] ; 676.8[\mathrm{M}-162]^{+} ;{ }^{1} \mathrm{H}$ NMR (aglycon) $\delta 6.91(1 \mathrm{H}, \mathrm{m}, \mathrm{H}-16), 3.69$ (1H, m, H-3), 0.90 (3H, s, Me-19), 0.91 (3H, s, Me-18), 2.28 (3H, d, H-21). (sugars) $\delta 4.40$ (d, J=7.4 Hz, H-1Gal), 3.61 (dd, $J=7.4$ and $9.0 \mathrm{~Hz}, \mathrm{H}-2 \mathrm{Gal}$ ), 3.54 (dd, $J=4.0$ and $9.0 \mathrm{~Hz}, \mathrm{H}-3 \mathrm{Gal}$ ), 4.03 (dd, $J=2.5$ and $4.0 \mathrm{~Hz}, \mathrm{H}-4 \mathrm{Gal}$ ), 3.60 (ddd, $J=2.5,2.5$ and $4.5 \mathrm{~Hz}, \mathrm{H}-5 \mathrm{Gal}$ ), 3.58 (dd, $J=4.5$ and $12.0 \mathrm{~Hz}, \mathrm{H}-6 \mathrm{Gal}$ ), 3.93 (dd, $J=2.5$ and $12.0 \mathrm{~Hz}, \mathrm{H}-6 \mathrm{bGal}$ ), 4.56 (d, $J=7.5 \mathrm{~Hz}, \mathrm{H}-1 \mathrm{Glc}$ ), 3.59 (dd, $J=7.5$ and $9.0 \mathrm{~Hz}, \mathrm{H}-2 \mathrm{Glc}$ ), 3.61 (dd, $J=9.0$ and $9.0 \mathrm{~Hz}, \mathrm{H}-3 \mathrm{Glc}$ ), 3.36 (dd, $J=9.0$ and $9.0 \mathrm{~Hz}, \mathrm{H}-4 \mathrm{Glc}$ ), 3.26 (ddd, $J=2.5,4.5$ and $9.0 \mathrm{~Hz}, \mathrm{H}-5 \mathrm{Glc}$ ), 3.61 (dd, $J=4.5$ and $11.5 \mathrm{~Hz}, \mathrm{H}-6 \mathrm{aGlc}$ ), 3.94 (dd, $J=2.5$ and $11.5 \mathrm{~Hz}, \mathrm{H}-6 \mathrm{bGlc}$ ), 4.69 (d, $J=7.5 \mathrm{~Hz}, \mathrm{H}-1 \mathrm{GlcI}$ ), 3.29 (dd, $J=7.5$ and $9.0 \mathrm{~Hz}, \mathrm{H}-2 \mathrm{GlcI}$ ), 3.37 (dd, $J=9.0 \mathrm{and} 9.0 \mathrm{~Hz}$, $\mathrm{H}-3 \mathrm{GlcI}$ ), 3.41 (dd, $J=9.0$ and $9.0 \mathrm{~Hz}, \mathrm{H}-4 \mathrm{GlcI}$ ), 3.41 (ddd, $J=2.5,4.5$ and $9.0 \mathrm{~Hz}, \mathrm{H}-5 \mathrm{GlcI}$ ), 3.83 (dd, $J=4.5$ and 11.5 $\mathrm{Hz}, \mathrm{H}-6 \mathrm{GGlcI}), 3.69$ (dd, $J=2.5$ and $11.5 \mathrm{~Hz}, \mathrm{H}-6 \mathrm{bGlcI})$. For ${ }^{13} \mathrm{C}$ NMR see Table 1.

\section{Conclusion}

Three new compounds, hyoscyamosides $\mathbf{B}$ (1), C (2) and $\mathbf{C}_{2}$ (3), together with seven known steroidal saponins (4-10) have been isolated from the seeds of Hyoscyamus niger $L$. for the first time. The structures of hyoscyamosides B (1), $\mathbf{C}$ (2) and $\mathbf{C}_{2}$ (3) were elucidated as 3-O- $\beta$-D-glucopyranosyl- (1 $\left.\rightarrow 3\right)$ - $\beta$-D- galactopyranoside - $(25 \mathrm{R})-5 \alpha-$

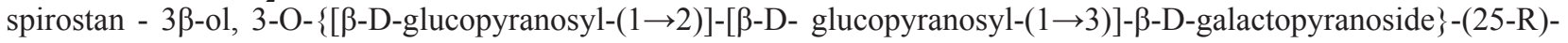
$5 \alpha$-spirostan-3 $\beta$-ol and 3-O $\beta$-D-glucopyranosyl $(1 \rightarrow 2)]$ - $\beta$-D-glucopyranosyl- $(1 \rightarrow 4)$ - $\beta$-D-galactopyranosyl-5 $\alpha$-pregn16-en-20-one-3 $\beta$-ol, respectively by means of physico-chemical methods. 


\section{Acknowledgments}

Thanks are due to the financial support from INTAS (The International Association for the Promotion of Cooperation with Scientists from the New Independent States). Also the authors are grateful to Dr. Assunta Napolitana from the Department of Pharmaceutical Sciences, University of Salerno for MS measurements.

\section{References}

[1] Zhang, R. S.; Ye, Y. P.; Shen, Y. M.; Liang, H. L.Tetrahedron 2000, 56, 3875-3879.

[2] Mellado, G. G.; Zubia, E.; Ortega, M. J.; Lopez-Gonzalez, P. J. Steroids 2004, 69, 291-299.

[3] Halaweish, F. T.; Huntimer, E.; Khalil, A. T. Phytochem. Anal. 2004, 15, 189-194.

[4] Yin, J.; Kouda, K.; Tezuka, Y.; Tran, Q. L.; Miyahara, T.; Chen, Y. J.; Kadota, S. J. Nat. Prod. 2003, 66, 646-650.

[5] Liu, H. W.; Xiong, Z.; Li, F.; Qu, G. X.; Kobayashi, H.; Yao, X. S. Chem. Pharm. Bull. 2003, 51, $1089-1091$.

[6] Deepak, D.; Srivastav, S.; Khare, A. In Herz, W., Kirby, G. W., Moore, R. E., Strglich, W., Tamm, Ch., Eds.; Progress in the chemistry of organic natural products; Springer: New York, 1997, 71, pp 169-325.

[7] Gutsu, E.V.; Kintya, P.K.; Lazur'evskii, G.V. Khimia Prirodnykh Soedinenii 1987, 2, 242-246.

[8] Imai, S.; Fujioka, S.; Murata, E.; Goto, M.; Kawasaki, T.; Yamauchi, T. Takeda Kenkyusho Nenpo 1967, 26, 76-83.

[9] Murakami, K.; Saijo, R.; Nohara, T.; Tomimatsu, T. Yakugaku Zasshi 1981, 101 (3), 275-279.

[10] Shvets, S. A.; Naibi, A. M.; Kintya, P. K. Khimiya Prirodnykh Soedinenii 1995, 2, 247-252. 